\title{
Identification of upregulated genes in laminarin-treated poplar (Populus alba $\times$ P. tremula var. glandulosa) suspension cells by suppression subtractive hybridization and cDNA microarray
}

\author{
By J-H. KIM ${ }^{1)}$, H. LEE ${ }^{1, *}$, E-K. BAE ${ }^{1)}$, H. SHIN ${ }^{1}$, J-S. LEE ${ }^{1)}$, K-S. KANG ${ }^{2)}$ and S-Y. PARK ${ }^{3)}$
}

(Received $26^{\text {th }}$ January 2013)

\begin{abstract}
Elicitors trigger defence responses in plant cells through signal transduction pathways, leading to accumulation of pathogenesis-related (PR) proteins and, eventually, pathogen resistance. To understand defence responses of hybrid poplar (Populus alba $\times$ P. tremula var. glandulosa), we isolated and characterized upregulated genes in poplar cells by laminarin-induced elicitation using suppression subtractive hybridization ( $\mathrm{SSH}$ ) and cDNA microarray approaches. A total of 1,269 clones in the SSH library were sequenced and a cDNA microarray, containing 265 unique subtracted clones, was fabricated. From the microarray results, 37 clones were found to be upregulated by laminarin treatment and their putative functions are discussed. Genes involved in signal transduction, transcriptional regulation, and phytohormone biosynthesis were upregulated. Other genes encoding PR proteins, peptidases, and an $\mathrm{ABC}$ transporter, as well as genes involved in lignification and protein synthesis and turnover, were also identified. Our results suggest that well-organized defence responses, from signal transduction to accumulation of PR proteins, are activated in poplar cells by laminarininduced elicitation and could contribute to resistance against pathogens.
\end{abstract}

Key words: Elicitor; Gene expression; Laminarin; Microarray; Poplar.

\section{Introduction}

Diseases and pests are a major factor in forest destruction, which is important in terms of decreasing forest resources and biodiversity, as well as economically (RALPH et al., 2006; LIPPERT et al., 2009). Rapid diffusion of insects and diseases, and even introduction of exogenous species, are threatening forest health worldwide (JONES et al., 2008). In Korea, about 167,084 ha of forest were damaged by diseases and pests in 2011 (Korea Forest Service, 2012). Therefore, it is important to understand plant defence mechanisms against pathogens in forest trees and to identify ways to improve these.

Experimental handling of pathogens can be problematic for researchers, because even a small error could result in their spread, potentially leading to devastation

\footnotetext{
1) Department of Forest Genetic Resources, Korea Forest Research Institute, Suwon 441-350, Republic of Korea.

2) Department of Forest Sciences, Seoul National University, Seoul 151-742, Republic of Korea.

3) Department of Horticultural Science, Chungbuk National University, Cheongju 361-763, Republic of Korea.

*) Corresponding author: Hyoshin LEE. Tel. +82-31-290-1174, Fax +82-31-290-1020. E-Mail: hslee@forest.go.kr
}

of nearby forests. Thus, extracts from pathogens or other living organisms, such as fungi, bacteria, and microorganisms, which are well known as elicitors, are frequently used to trigger plant defence responses (LI et al., 2012). Among the various kinds of elicitors, laminarin, composed of $\beta-1,3$-glucan, extracted from the brown algae Laminaria digitata, induces a variety of defence reactions in tobacco (KLARZYNSKI et al., 2000), grapevine (AzIZ et al., 2007), and potato (ARASIMOWICZ-JELONEK et al., 2013). Laminarin activates defence mechanisms through signal transduction pathways and this is accompanied by alkalization of incubation medium and active oxygen species (AOS) production as signals of pathogen attack, inducing the accumulation of pathogenesis-related (PR) proteins; eventually pathogen resistance, such as systemic acquired resistance, is triggered (AzIZ et al., 2007).

Plant cell suspension culture provides a high degree of both genetic and physiological homogeneity and is not technically challenging (LEE et al., 2007). The technique is also useful in examining responses of cells to changes in culture conditions, cell division, and growth, as most genes involved in development and environmental responses are expressed at similar levels in culture to those found in whole plants (MENGEs et al., 2003). Thus, a number of plant suspension cell systems, including Arabidopsis (HAAPALAINEN et al., 2012) and tobacco (DoKLADAL et al., 2012), have been used to identify defence reactions provoked by treatment with elicitors.

Populus is used as a model system to study tree growth and development (WANG et al., 2011), wood formation (ZAWASKI et al., 2012), and environmental responses (CHEN et al., 2012); however, despite the widespread devastation of forest trees by invading insects, fungi, and pathogens, only limited information is available on the defence mechanisms of trees.

A functional genomics approach to characterize inducible defences against insect herbivory of Populus trichocarpa $\times$ deltoides by the caterpillar, Malacosoma disstria, revealed that genes involved in defence, secondary metabolism, transport, and transcriptional regulation are significantly induced in this system (RALPH et al., 2006). YUAN et al. (2008) identified 40 differentially expressed proteins, in functional groups of protein synthesis, metabolism, and defence responses, in Populus tomentosa after infection with black spot disease (Marssonina brunnea). Thus, it is clear that forest trees have developed resistance mechanisms against diseases, which are regulated at the molecular level. In this study, as a first step to elucidating the defence responses of 
poplar, we employed suppression subtractive hybridization (SSH) and cDNA microarray approaches to identify upregulated and newly induced genes in poplar cells by laminarin-induced elicitation. In addition, differential expression of isolated genes was verified by real-time quantitative PCR (RT-qPCR).

\section{Materials and Methods}

\section{Plant materials and growth conditions}

Poplar (Populus alba $\times$ P. tremula var. glandulosa) suspension cells were maintained as described previously (LEE et al., 2007). Briefly, $1 \mathrm{~g}$ (fresh mass) of suspension cells were transferred to $100 \mathrm{ml} \mathrm{MS}$ liquid medium, containing $1 \mathrm{mg} \mathrm{l}^{-1}$ 2,4-dichlorophenoxyacetic acid, $0.1 \mathrm{mg} \mathrm{l}^{-1}$ naphthalene acetic acid, and $0.01 \mathrm{mg} \mathrm{l}^{-1}$ 6-benzylaminopurine, and maintained on a gyratory shaker with agitation at $130 \mathrm{rpm}$ in a culture room at 22 $\pm 1^{\circ} \mathrm{C}$. Five-day-old cells were treated with laminarin. To determine the effect of laminarin, the $\mathrm{pH}$ of culture medium was measured with an electrode every $5 \mathrm{~min}$, starting $10 \mathrm{~min}$ before the treatment. The $\mathrm{pH}$ values of sterilized water-treated cells were also measured under the same conditions. All measurements were carried out in triplicate. Amounts and duration of treatments are indicated in the figure legends. Cells were harvested by vacuum filtration, frozen in liquid nitrogen, and stored at $-70^{\circ} \mathrm{C}$ for RNA extraction.

\section{Construction of subtracted cDNA library and sequence analysis}

Total RNA was extracted using TRI regent (Molecular Research Center, Cincinnati, OH, USA) and mRNA was isolated using the Oligotex mRNA Mini Kit (Qiagen, Valencia, CA, USA). SSH was performed with $2 \mu \mathrm{g}$ of mRNA from water-treated control cells as the driver and the same amount of mRNA from laminarin-treated cells as the tester using a PCR-Select cDNA subtraction kit (Clontech, Palo Alto, CA, USA). The subtracted cDNA library was constructed by cloning the subtracted cDNAs into the pGEM-T Easy vector (Promega, Madison, WI, USA) and then transforming into Escherichia coli, strain JM109 (Promega).

Plasmid DNA was purified using an AccuPrep Plasmid Extraction kit (Bioneer, Deajeon, Korea) and sequenced using a Dynamic ET Terminator Cycle Sequencing kit (Amersham, Uppsala, Sweden) on an RISA-384 automatic sequencer (Shimazu, Tokyo, Japan). The BLASTX algorithm was used to search the GenBank non-redundant (nr) protein database and sequences with the scores $\geq 80$ were considered to have significant homology.

\section{cDNA microarray analysis}

cDNA microarray fabrication, probe preparation, hybridization, and data analysis were conducted as previously described (LEE et al., 2007). Briefly, cDNAs representing 265 unique genes from the $\mathrm{SSH}$ library were amplified with a T7 and SP6 primer set, and the PCR products were spotted onto silanized glass slides (UltraGAPS $^{\mathrm{TM}}$, Corning Lifescience, CA, USA). For each experimental condition, $3 \mu \mathrm{g}$ of total RNA was reverse transcribed in the presence of Cy3-dUTP or Cy5-dUTP (Amersham) and used for microarray hybridization. Slides were scanned using an Axon GenePix 4000B scanner (Axon Instruments, Foster, CA, USA) and images quantified using GenePix Pro 4.1 (Axon Instruments). Normalization and statistical analyses were performed using GeneSpringGX 7.3.1 (Silicon Genetics, Redwood, CA, USA). Fold change was calculated by dividing the median normalized red channel intensity by the median normalized green channel intensity.

\section{Real-time quantitative PCR validation}

Primers for three genes randomly selected from those identified as differentially expressed by microarray analysis were designed using IDT SciTools (http://www. idtdna.com) (Table 1). A gene encoding ubiquitin-conjugating enzyme (GenBank accession number CX654542) was used as a reference. Two micrograms of total RNA was reverse transcribed, diluted 100-fold with sterile water, and used as a template. Each $20 \mu \mathrm{l}$ reaction mixture contained $1 \mu \mathrm{l}$ of the diluted-template, $10 \mu \mathrm{l}$ of $2 \times$ SYBR $^{\circledR}$ Green PCR Master Mix (Applied Biosystems, Foster City, CA, USA), $1 \mu \mathrm{l}$ each of the $10 \mu \mathrm{M}$ forward and reverse primers, and $7 \mu \mathrm{l}$ of nuclease-free water. The cycling conditions for amplification included $10 \mathrm{~min}$ at $95^{\circ} \mathrm{C}$ for polymerase activation, followed by 40 cycles of $95^{\circ} \mathrm{C}$ for $15 \mathrm{sec}$ and $60^{\circ} \mathrm{C}$ for $1 \mathrm{~min}$. For amplicon detection, PCR was performed on DNA Engine

Table 1. - List of primers used in RT-qPCR.

\begin{tabular}{cccc}
\hline Clone ID & Orientation & Primer sequence $\left(5^{\prime} \rightarrow 3^{\prime}\right)$ & $\begin{array}{c}\text { Product } \\
\text { size }(\mathrm{bp})\end{array}$ \\
\hline \multirow{2}{*}{ P006004A08 } & Forward & ACCATGCCGCAGTTGATAGTGTCT & 113 \\
& Reverse & TCCCGACATCCTTGGCCACAATAA & \\
P006002G03 & Forward & TGAGATGATGACACGAGCAAGGCT & 101 \\
& Reverse & TGGAGGTGTCATGCTCTGGAACAA & \\
P006004D09 & Forward & TGTTCCAGCTGGGTGGACAGTAAT & 96 \\
& Reverse & CAGCGCCAAGGATTGAACGTAACT & \\
CX654542 ${ }^{*}$ & Forward & AGACATGGAGGCTTCTGGCATCAA & 104 \\
& Reverse & TGCCACCTTCATAAGGAGAGCTGA & \\
\hline
\end{tabular}

* GenBank accession number for ubiquitin-conjugating enzyme. 
OPTICON $^{\mathrm{TM}}$ continuous fluorescence detection system (MJ Research, Waltham, MA, USA) and fluorescence was measured at the end of each cycle. Melting curves were generated by denaturing the reaction mixture from $60^{\circ} \mathrm{C}$ to $95^{\circ} \mathrm{C}$, with data capture every $0.2^{\circ} \mathrm{C}$. Relative transcript quantity was determined using the $\Delta \Delta \mathrm{Ct}$ method (PFAFFL, 2001) by comparing the data for each gene in the laminarin-treated cells with that for watertreated control cells. The PCR products were confirmed by $2 \%$ agarose gel electrophoresis to verify that a single product of the expected size was produced. PCR was conducted in duplicate for all primer pairs.

\section{Results and Discussion}

\section{Medium alkalization}

When pathogens attack plants, plant cells detect them using receptors encoded by $R$ genes, and the early responses of plants are through signal transduction (BLume et al., 2000). Calcium $\left(\mathrm{Ca}^{2+}\right)$ and hydrogen $\left(\mathrm{H}^{+}\right)$ cations move into the cell and potassium cations $\left(\mathrm{K}^{+}\right)$ and chlorine anions $\left(\mathrm{Cl}^{-}\right)$are transported across the plasma membrane against the $\mathrm{Ca}^{2+}$ gradient (AzIZ et al., 2007). Elicitors also motivate ion fluxes across plant cell membranes, leading to alkalization of the incubation medium (AzIZ et al., 2007). In this study, we monitored the $\mathrm{pH}$ of the medium after laminarin treatment. The results showed that the $\mathrm{pH}$ of the medium increased significantly as a result of treatment with a concentration of $1 \mathrm{mg} \mathrm{ml}^{-1}$ laminarin, with the highest $\mathrm{pH}$ observed 35 min after the treatment (Fig. 1). The $\mathrm{pH}$ then decreased slowly, returning to the initial level $95 \mathrm{~min}$ after treatment. The $\mathrm{pH}$ of sterile water-treated poplar cells did not increase. Suspension cells of both tobacco (KLARZYNSKI et al., 2000) and grapevine (AzIZ et al., 2007) showed the same pattern of $\mathrm{pH}$ changes when treated with Botrytis cinerea and laminarin, respectively. The alka- lization response was detected within $5 \mathrm{~min}$ and $20 \mathrm{~min}$ in tobacco and grapevine cells, respectively, after treatment. The difference in the response time might be due to the difference on plant species, growth conditions and elicitor treatment conditions. Thus, these results imply that poplar cells recognized laminarin as an elicitor and initiated defence responses, observable as ion transition in this study.

\section{SSH library construction}

To isolate laminarin-induced transcripts from poplar cells, we constructed two subtracted cDNA libraries using tester mRNA from cells treated with laminarin for $5 \mathrm{~min}$ and $6 \mathrm{~h}$, and driver mRNA from water-treated cells. A total of 1,269 clones from the two libraries were sequenced. The average read length of the total 963 high quality sequences derived from these, after trimming low quality regions, vector, and adaptor sequences, was $386 \mathrm{bp}$. The ESTs were submitted to GenBank with accession numbers GE298864-GE299826.

\section{cDNA microarray analysis}

A cDNA microarray, consisting of 265 unique subtracted cDNAs, was fabricated to allow identification of genes differentially expressed in response to laminarininduced elicitation. RNA samples from cells treated with laminarin were collected at $5 \mathrm{~min}, 5 \mathrm{~h}$, and $24 \mathrm{~h}$ after treatment since it was our intention to investigate the early responses of poplar cells, along with water-treated control cells at the same time points, and were used for microarray hybridization in two individual experiments. From the these experiments, 37 clones with ratios (treated/untreated) of more than 1.5-fold were identified as significantly altered in expression in response to treatment with laminarin (Table 2). Among these clones, 12 showed upregulation over all three time points, three were upregulated only at $5 \mathrm{~min}$ after treatment, nine

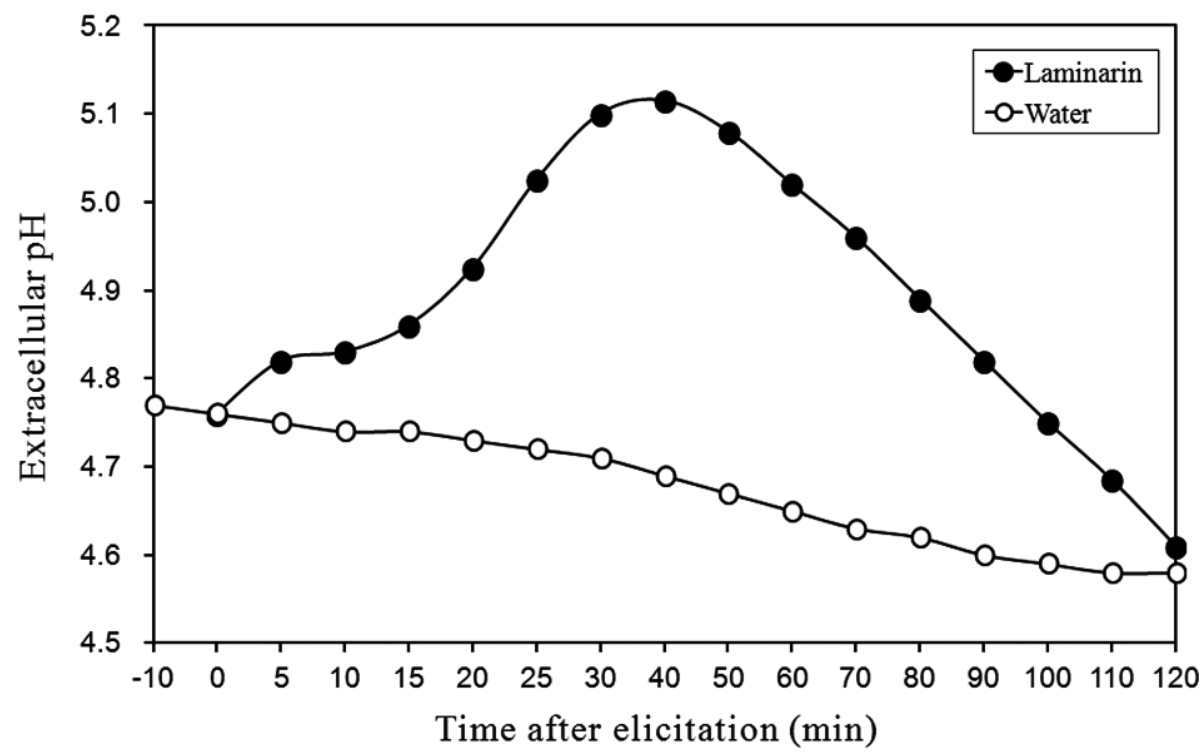

Figure 1. - Alkalization of the culture medium. Variations in the $\mathrm{pH}$ of culture medium after treatment of poplar cell suspension cultures at time 0 with $1 \mathrm{mg} \mathrm{ml}^{-1}$ laminarin (closed circles) or water (open circles). The $\mathrm{pH}$ of the cell culture medium was monitored every $5 \mathrm{~min}$. 
only at $5 \mathrm{~h}$, and five were only at $24 \mathrm{~h}$. Two clones showed upregulation at both $5 \mathrm{~min}$ and $5 \mathrm{~h}$ after treatment and the remaining six were upregulated at both 5 and $24 \mathrm{~h}$.

\section{Characterization of the upregulated genes}

All 37 upregulated clones were functionally annotated by comparison against the GenBank nr protein database using BLASTX; 25 clones had similarity to known proteins (score $\geq 80$ ). Gene-by-gene analysis was conducted to obtain detailed information on the responses of poplar cells after laminarin-induced elicitation (Table 2).
Plant defence responses are regulated by complex regulatory networks of signal transduction and transcriptional regulation (SPOEL and DONG, 2012). Cell surface receptors sense environmental changes and transduce external signals via activated signaling pathways to trigger defence responses (KIM et al., 2009). Receptorlike protein kinases sense potential pathogens by recognizing elicitors (HEESE et al., 2007). In our dataset, a gene encoding receptor-like protein kinase 3 (PO05008C01) was upregulated at both 5 and $24 \mathrm{~h}$ after treatment with laminarin. Transcription factors, which bind to cis-elements in the promoters of defence genes, play pivotal roles in the expression of defence genes. A

Table 2. - Genes upregulated in poplar cells by laminarin-induced elicitation.

\begin{tabular}{|c|c|c|c|c|c|}
\hline \multirow{2}{*}{ Clone ID } & \multirow{2}{*}{ Description } & \multirow{2}{*}{$\begin{array}{c}\text { BLASTX } \\
\text { score }\end{array}$} & \multicolumn{3}{|c|}{ Ratio } \\
\hline & & & $5 \mathrm{~min}$ & $5 \mathrm{~h}$ & $24 \mathrm{~h}$ \\
\hline PO06004H05 & threonine endopeptidase & $2 \mathbf{1 5}$ & 1.55 & 1.56 & 1.54 \\
\hline P005008D08 & translation elongation factor $1 \mathrm{~A}-8$ & 314 & 2.13 & 2.13 & 1.70 \\
\hline PO06001C06 & peptidase M & 284 & 1.95 & 2.18 & 1.92 \\
\hline$P 000001 C 05$ & hypersensitive-induced reaction protein l & 177 & 1.77 & 1.71 & 1.59 \\
\hline $\mathrm{PO} 06001 \mathrm{C} 12$ & 14-3-3 protein & 319 & 1.60 & 1.60 & 1.65 \\
\hline PO0G002G03 & acidic class III chitinase & 276 & 1.64 & 2.64 & 2.80 \\
\hline PO06004G09 & unknown & & 1.62 & 2.02 & 1.71 \\
\hline PO050081101 & unknown & & 1.70 & 1.96 & 1.80 \\
\hline PO05004D03 & unknown & & 1.58 & 1.62 & 1.56 \\
\hline PO050061107 & unknown & & 1.70 & 1.89 & 2.17 \\
\hline PO06001C08 & unknown & & 2.26 & 2.14 & 1.78 \\
\hline PO0500lE10 & unknown & & 1.56 & 1.86 & 1.88 \\
\hline PO05008F03 & $40 \mathrm{~S}$ ribosomal protein $\mathrm{S} 11$ & 115 & 1.86 & 1.54 & 1.16 \\
\hline PO05007F 12 & pyruvate decarboxylase family protein & 189 & 1.50 & 1.56 & 1.46 \\
\hline POO5008H03 & 40 S ribosomal protejn S15-like protein & 169 & 1.67 & 1.29 & 0.99 \\
\hline PO06002D 10 & acetyl-coA dehydrogenase, pulative & 98 & 1.52 & 1.47 & 1.44 \\
\hline РО05003B02 & unknown & & 1.53 & 1,39 & 1.34 \\
\hline PO05007F04 & LHI'1 (lysine histidine transporter 1) & 109 & 1.46 & 1.71 & 1.33 \\
\hline PO06003D08 & FAD-linked oxidoreductase 2 & 139 & 1.45 & 1.61 & 1.41 \\
\hline PO06006E09 & PDR-type $A B C$ transporter 2 & 269 & 1.40 & 1.61 & 1.39 \\
\hline PO06003D09 & NADP-dependent oxidoreductase, putative & 262 & 1.24 & 1.52 & 1.34 \\
\hline PO06002DO2 & class III peroxidase & 278 & 1.24 & 1.55 & 1.10 \\
\hline $\mathrm{PO} 06007 \wedge 11$ & plasma membrane $\mathrm{H}^{+} \Lambda$ TPase & 199 & 1.19 & 1.58 & 1.14 \\
\hline РО05002B09 & trans-cinnamate 4-hydroxylase & 181 & 1.14 & 1.58 & 1.35 \\
\hline $\mathrm{PO} 06008 \mathrm{C} 02$ & S-adenosyl-L-methionine synthetase & 162 & 1,12 & 1.63 & 1,02 \\
\hline PO06003G07 & cafleoyl-CoA-3-O-methyltransferase & 346 & 1.07 & 1.57 & 1.37 \\
\hline $\mathrm{P} 006001 \wedge 06$ & polygalacturonase-inhibiting protein 4 & 213 & 1.21 & 1.47 & 1.66 \\
\hline PO06001G10 & basic helix-loop-helix (bHLH) family protein & 109 & 1.11 & 1.45 & 1.58 \\
\hline POO6008E04 & TET8 (tetraspaniti8) & 182 & 0.99 & 1.13 & 1.56 \\
\hline POO5004H12 & unknown & & 1.13 & 1.46 & 1.56 \\
\hline POO6002F0I & unknowı & & 0.93 & 1.26 & 1.59 \\
\hline PO06004C10 & pulative pathogenesis-related protein & 228 & 1.49 & 2.00 & 1.70 \\
\hline PO05008C01 & putative receptor-like protein kinase 3 & 208 & 1.40 & 1.70 & 1,85 \\
\hline PO06004D09 & cylochrome $\mathrm{P} 450$ family protein & 119 & 1.27 & 2.31 & 1.68 \\
\hline $\mathrm{P} 006004 \wedge 08$ & unknown & & 1.43 & 2.01 & 1.78 \\
\hline PO06006E10 & unknown & & 1.42 & 1.66 & 1.58 \\
\hline PO06003B 10 & unknown & & 1.40 & 1.61 & 1.56 \\
\hline
\end{tabular}


gene for the basic helix-loop-helix (bHLH) family protein (PO06001G10) was upregulated at $24 \mathrm{~h}$ after laminarin treatment. bHLH family proteins are known to play a role in the JA signaling pathway (PAUwELs and Goossens, 2011). The highly conserved eukaryotic dimeric molecules, 14-3-3 proteins, play a central role in the regulation of the activities of many transcription factors and other signaling proteins, including kinases, in the MAP cascade, which has important roles in development, stress, and disease responses (LALLE et al., 2005; RoBB et al., 2007). Levels of jasmonic acid and ethylene, both of which are important signaling molecules in the activation of defence genes (MITTLER and CHEUNG, 2004), are also regulated by 14-3-3 proteins. This coordinated expression of regulatory proteins involved in complex signaling pathways induces biosynthesis of phytohormones, such as jasmonic acid and ethylene, and finally results in the synthesis of PR proteins (ALMAGRO et al., 2009). A gene encoding the 14-3-3 protein, PO06001C12, was upregulated over all three time points after laminarin treatment.

Two genes involved in phytohormone biosynthesis were upregulated by laminarin-induced elicitation in poplar cells. A gene for a cytochrome P450 family protein was upregulated at both 5 and $24 \mathrm{~h}$ after treatment. Cytochrome P450 proteins are involved in the biosynthesis of plant primary and secondary metabolites and also in jasmonic acid biosynthesis (GUTTIKONDA et al., 2010). In many plants, cytochrome P450s are highly induced by elicitors, wounding, xenobiotics, and pathogens (BoLwELL et al., 1994). S-adenosyl-L-methionine synthetase catalyzes the conversion of methionine into S-adenosylmethionine and is also involved in the biosynthesis of polyamines and ethylene (YUAN et al., 2008). A gene for S-adenosyl-L-methionine synthetase, PO06008C02, was transiently induced at $5 \mathrm{~h}$ after treatment with laminarin. It is well known that phytohormones, including jasmonic acid and ethylene, are closely associated with plant defence responses against pathogen attacks (YUAN et al., 2008).

PR proteins are induced in response to pathogens and have protective roles (SELS et al., 2008). A gene for the acidic class III chitinase, PR-8 (PO06002G03), was upregulated over all three time points after laminarin treatment. Chitinase is thought to have a role in defence against pathogenic attacks, as chitin is a component of fungal cell walls and of the exoskeleton of insects. This gene was also highly induced in various other plants by wounding, jasmonic acid, or ethylene treatment (RAKWAL et al., 2004). Another gene for a putative PR protein, PO06004C10, was also upregulated by laminarin. Signal transduction pathways triggered by pathogen attacks lead to the reinforcement of cell walls and lignification (AlmAGRo et al., 2009). Genes involved in lignification were upregulated by laminarin treatment. Genes encoding caffeoyl-CoA-3-O-methyltransferase, CCoAOMT (PO06003G07), and a class III peroxidase, PO06002D02, were upregulated $5 \mathrm{~h}$ after treatment. CCoAOMT participates in lignin biosynthesis, and class III peroxidase is involved in broad range of physiological processes, including lignin and suberin formation, as well as crosslinking of cell wall components (ALMAGRo et al.,
2009). In potato, it was suggested that CCoAOMT and peroxidase may play a role in the suberization process in damaged epidermis (BAREL and GINZBERG, 2008).

Peptidases play important roles in protein synthesis and turnover. They facilitate the turnover of damaged proteins, directly inactivate digestive enzymes, and modulate induced defences as activators of peptide hormones in plant defence signaling (RALPH et al., 2006). Two genes encoding peptidases were upregulated by the treatment. Genes for a threonine endopeptidase, PO06004H05, and peptidase M, PO06001C06, were upregulated over all three time points investigated. Alongside the upregulation of peptidases, three genes

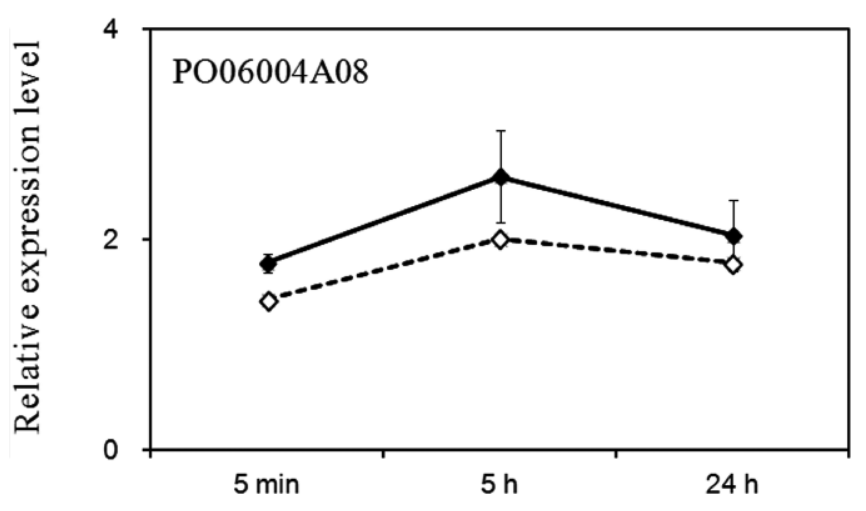

Time after treatment

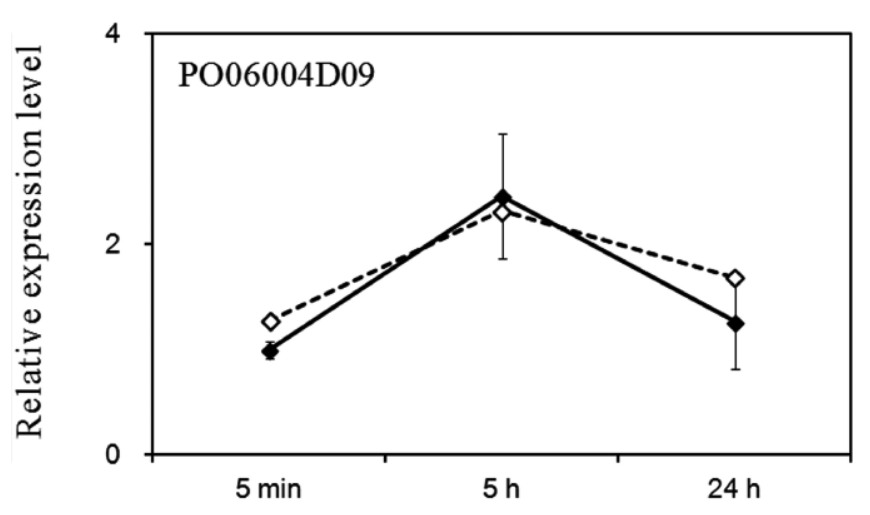

Time after treatment

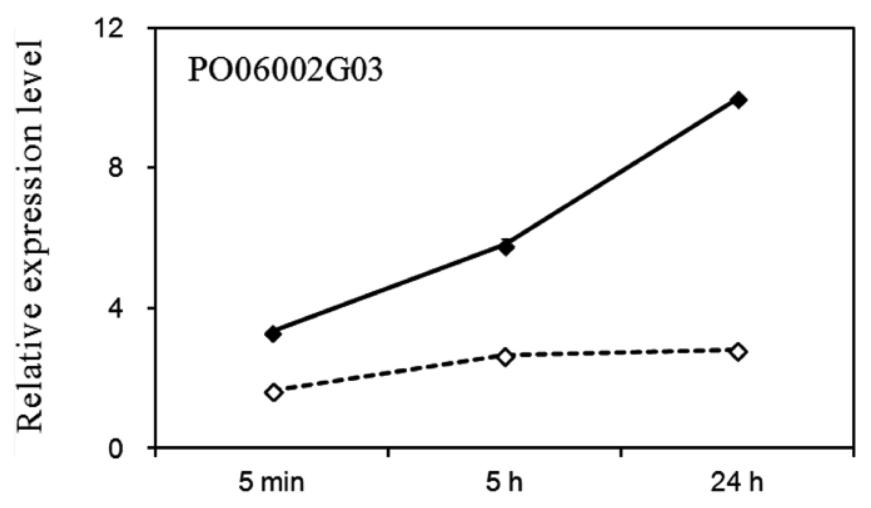

Time after treatment

Figure 2. - Real-time quantitative PCR results (solid line) of the randomly selected three transcripts and their correlation with microarray data (dotted line). Error bars show the standard deviation of expression levels at each time point. 
involved in protein synthesis were also upregulated by the treatment; one gene for translation elongation factor 1A-8, PO05008D08, and two genes for 40S ribosomal proteins, PO05008F03 and PO05008H03, were differentially expressed within 5 min after treatment. Highly increased expression of these proteins as a result of pathogen attacks has been reported in many plants, and their accumulation may be involved in the synthesis of certain defence-related proteins (YUAN et al., 2008).

Programmed cell death (PCD) is important in various aspects of differentiation, development, and environmental responses, including pathogen attack (CoLL et al., 2011). A hypersensitive reaction, involving PCD, provides resistance against many pathogens (RoBB et al., 2007). A gene for hypersensitive-induced reaction protein 1, PO06001C05, was induced within 5 min of treatment with laminarin and its expression was maintained until $24 \mathrm{~h}$. It is suggested that ABC proteins in plants may be directly involved in defence via transport of signaling molecules, such as jasmonic acid, and phytochemicals, such as terpenoid (RALPH et al., 2006). A gene for a PDR-type ABC transporter (PO06006E09) was upregulated $5 \mathrm{~h}$ after treatment. Trans-cinnamate 4-hydroxylase, $\mathrm{C} 4 \mathrm{H}$ (PO05002B09), is involved in synthesizing various secondary metabolites that participate in plant development and adaptation (BAEK et al., 2008). Induction of $\mathrm{C} 4 \mathrm{H}$ as a plant defence response to fungal infection is well documented (SCHMIDT et al., 2004).

\section{Verification of microarray data by RT-qPCR}

To verify the changes in mRNA abundance identified by microarray analysis, we selected three genes that were significantly upregulated by laminarin-induced elicitation and analyzed their expression by RT-qPCR. All three genes showed higher expression ratios by RTqPCR than those determined by the microarray, showing that both techniques identified increased expression of these three genes (Fig. 2).

\section{Conclusions}

In this study, we have isolated and characterized upregulated genes related to defence responses in poplar suspension cells by laminarin-induced elicitation. The number of significantly upregulated genes in this study represents only a small fraction of the transcriptome of poplar cells; nevertheless, our data illustrate the considerable breadth of the modulation of the defence responses of these cells, from signal transduction to accumulation of PR proteins. The organized upregulation of genes involved in signal transduction, transcriptional regulation, and phytohormone biosynthesis suggest that our dataset may be a good starting point to understand the molecular responses of the tree to pathogen attacks. We also discuss changes in expression of genes encoding PR proteins, peptidases, and an ABC transporter, as well as genes involved in lignification, and protein synthesis and turnover. We are confident that the upregulated genes identified in this study are likely to be confirmed as contributing to the acquisition of resistance against pathogens through more detailed functional characterization.

\section{References}

Almagro, L., R. L. V. Gómez, S. Belchi-Navarro, R. Bru, R. A. BARCEló and M. A. PEDREÑo (2009): Class III peroxidases in plant defence reactions. J. Exp. Bot. 60: $377-390$

Arasimowicz-Jelonek, M., A. Kosmala, L. Janus, D. ABramowski and J. FlorYSZAK-WiECZOREK (2013): The proteome response of potato leaves to priming agents and S-nitrosoglutathione. Plant Sci. 198: 83-90.

Aziz, A., A. Gauthier, A. Bézier, B. Poinssot, J. M. Joubert, A. Pugin, A. Heyraud and F. Baillieul (2007): Elicitor and resistance-inducing activities of $\beta-1,4$ cellodextrins in grapevine, comparison with $\beta-1,3$ glucans and $\alpha-1,4$ oligogalacturonides. J. Exp. Bot. 24: 1-10.

BAeK, M. H., B. Y. Chung, J. H. KIM, J. S. Kim, S. S. LeE, B. C. AN, I. J. LEE and T. H. KIM (2008): cDNA cloning and expression pattern of cinnamate-4-hydroxylase in the Korean black raspberry. BMB Rep. 41: 529-536.

BAREL, G. and I. GINZBERG (2008): Potato skin proteome is enriched with plant defence components. J. Exp. Bot. 59: 3347-3357.

Blume, B., T. Nürnberger, N. NAss and D. Scheel (2000): Receptor-mediated increase in cytoplasmic free calcium required for activation of pathogen defense in parsley. Plant Cell 12: 1425-1440.

Bolwell, G. P., K. BozAK and A. Zimmerlin (1994): Plant cytochrome P450. Phytochemistry 37: 1491-1506.

Chen, L., Y. Zhang, Y. Ren, J. Xu, Z. Zhang and Y. Wang (2012): Genome-wide identification of cold-responsive and new microRNAs in Populus tomentosa by highthroughput sequencing. Biochem. Biophys. Res. Commun. 417(2): 892-896.

Coll, N. S., P. EpPle and J. L. DANGL (2011): Programmed cell death in the plant immune system. Cell Death Differ. 18(8): 1247-1256.

Dokládal, L., M. OboR̆IL, K. STEJSKal, Z. ZdRÁHAL, N. PtáC̆KOVÁ, R. ChalOUPKOVÁ, J. DAmBorskÝ, T. KAS̆PAROVSKÝ, S. JEANDROZ, M. ŽD’ÁRSKÁ and J. LOCHMAN (2012): Physiological and proteomic approaches to evaluate the role of sterol binding in elicitin-induced resistance. J. Exp. Bot. 63(5): 2203-2215.

Guttikonda, S. K., J. Trupti, N. C. Bisht, H. Chen, Y. C. An, S. PANDEY, D. Xu and O. Yu (2010): Whole genome co-expression analysis of soybean cytochrome P450 genes identifies nodulation-specific P450 monooxygenases. BMC Plant Biol. 10: 243.

HaApalainen, M., A. Dauphin, C. M. Li, G. Bailly, D. Tran, J. Briand, F. Bouteau and S. TAIRA (2012): HrpZ harpins from different Pseudomonas syringae pathovars differ in molecular interactions and in induction of anion channel responses in Arabidopsis thaliana suspension cells. Plant Physiol. Biochem. 51: 168-174.

Heese, A., D. R. Hann, S. Gimenez-Ibanez, A. M. Jones, K. He, J. Li, J. I. Schroeder, S. C. Peck and J. P. RATHJEN (2007): The receptor-like kinase SERK3/BAK1 is a central regulator of innate immunity in plants. Proc. Natl. Acad. Sci. U.S.A. 104: 12217-12222.

Jones, J. T., M. Moens, M. Mota, H. Li and T. KikUChi (2008): Bursaphelenchus xylophilus: opportunities in comparative genomics and molecular host-parasite interactions. Mol. Plant Pathol. 9: 357-368.

Kim, H. S., M. S. JunG, S. M. LeE, K. E. Kim, H. Byun, M. S. Choi, H. C. Park, M. J. Cho and W. S. Chung (2009): An S-locus receptor-like kinase plays a role as a negative regulator in plant defense responses. Biochem. Biophys. Res. Commun. 381: 424-428. 
Klarzynski, O., B. Plesse, J. M. Jouber, J. C. Yvin, M. Kopp, B. KlOAREG and B. Fritig (2000): Linear $\beta$-1,3-glucans are elicitors of defense responses in tobacco. Plant Physiol. 124: 1027-1037.

Korea Forest SERVICE (2012): Statistical yearbook of forestry. Retrieved from http://www.forest.go.kr/ newkfsweb/cop/bbs/selectBoardList.do?bbsId= BBSMSTR_1064\&mn=KFS_04_06.

LALle, M., S. Visconti, M. MARRA, L. CAMONI, R. VElasco and P. ADUCCI (2005): ZmMPK6, a novel maize MAP kinase that interacts with $14-3-3$ proteins. Plant Mol. Biol. 59: 713-722.

Lee, H., E. K. Bae, S. Y. Park, A. Sjödin, J. S. Lee, E. W. NoH and S. JANSSON (2007): Growth-phase-dependent gene expression profiling of poplar (Populous alba $\times$ Populus tremula var. glandulosa) suspension cells. Physiol. Plantarum 131: 599-613.

Li, S. T., P. Zhang, M. Zhang, C. H. Fu, C. F. Zhao, Y. S. Dong, A. Y. GUO and L. J. YU (2012): Transcriptional profile of Taxus chinensis cells in response to methyl jasmonate. BMC Genomics 13: 295.

Lippert, D. N., S. G. Ralph, M. Phillips, R. White, D. Smith, D. Hardie, J. Gershenzon, K. Ritland, C. H. BorCHERS and J. BoHLMANN (2009): Quantitative iTRAQ proteome and comparative transcriptome analysis of elicitor-induced Norway spruce (Picea abies) cells reveals elements of calcium signaling in the early conifer defense response. Proteomics 9: 350-367.

Menges, M., L. Hennig, W. Gruissem, J. A. H. Murray (2003): Genome-wide expression in an Arabidopsis cell suspension. Plant Mol. Biol. 53: 423-442.

MittleR, R. and A. Y. Cheung (2004): Cell death in plant development and defense, in When cells die II: a comprehensive evaluation of apoptosis and programmed cell death, edited by R. A. LOCKSHIN and Z. ZAKERI, Wiley, New York.

Pauwels, L. and A. Goossens (2011): The JAZ Proteins: A Crucial Interface in the Jasmonate Signaling Cascade. Plant Cell 23(9): 3089-3100.

PfAFFL, M. W. (2001): A new mathematical model for relative quantification in real-time RT-PCR. Nucleic Acids Res. 29: 2002-2007.

RAKWAL, R., G. YANG and S. Komatsu (2004): Chitinase induced by jasmonic acid, methyl jasmonate, ethylene and protein phosphatase inhibitors in rice. Mol. Biol. Rep. 31: 113-119.
RAlPH, S., C. OdDy, D. CoOper, H. Yueh, S. JANCSIK, N. Kolosova, R. N. Philippe, D. Aeschliman, R. White, D. Huber, C. E. Ritland, F. Benoit, T. Rigby, A. NAntel, Y. S. Butterfield, R. KirkPatrick, E. Chun, J. Liu, D. Palmquist, B. Wynhoven, J. Stott, G. Yang, S. Barber, R. A. Holt, A. Siddiqui, S. J. Jones, M. A. Marra, B. E. Ellis, C. J. Douglas, K. Ritland and J. BoHLMANN (2006): Genomics of hybrid poplar (Populus trichocarpa $\times$ deltoides) interacting with forest tent caterpillar (Malacosoma disstria): normalized and full-length cDNA libraries, expressed sequence tags, and a cDNA microarray for the study of insectinduced defences in poplar. Mol. Ecol. 15: 1275-1297.

RoBb, J., B. LEE and R. N. NAZAR (2007): Gene suppression in a tolerant tomato-vascular pathogen interaction. Planta 226: 299-309.

Schmidt, K., B. Heberle, J. Kurrasch, R. Nehls and D. J. STAHL (2004): Suppression of phenylalanine ammonia lyase expression in sugar beet by the fungal pathogen Cercospora beticola is mediated at the core promoter of the gene. Plant Mol. Biol. 55: 835-852.

Sels, J., J. Mathys, B. M. De Coninck, B. P. Cammue and M. F. DE Bolle (2008): Plant pathogenesis-related (PR) proteins: a focus on PR peptides. Plant Physiol. Biochem. 46(11): 941-950.

Spoel, S. H. and X. Dong (2012): How do plants achieve immunity? Defence without specialized immune cells. Nat. Rev. Immunol. 12(2): 89-100.

WANG, J., S. ANDERSSON-GUNNERÅS, I. GABOREANU, M. HertzBerg, M. R. Tucker, B. Zheng, J. LeŚNiewskA, E. J. Mellerowicz, T. LAuX, G. SANDBERG and B. Jones (2011): Reduced expression of the SHORT-ROOT gene increases the rates of growth and development in hybrid poplar and Arabidopsis. PLoS One 6(12): e28878.

YuAN, K., B. Zhang, Y. Zhang, Q. Cheng, M. WANG and M. HUANG (2008): Identification of differentially expressed proteins in poplar leaves induced by Marssonina brunnea f. sp. Multigermtubi. J. Genet. Genomics 35: 49-60.

Zawaski, C., C. Ma, S. H. Strauss, D. French, R. Meilan and V. B. BusOv (2012): PHOTOPERIOD RESPONSE 1 (PHOR1)-like genes regulate shoot/root growth, starch accumulation, and wood formation in Populus. J. Exp. Bot. 63(15): 5623-5634. 